\title{
Aspects of Motivation and Engagement of Employees in Their Work Based on the Example of Mining Companies
}

\author{
Barbara KOWAL ${ }^{1)}$, Małgorzata WYGANOWSKA ${ }^{2)}$
}

1) Ph.D., DSc, Eng.; AGH University of Science and Technology, Faculty of Mining and Geoengineering, Cracow, Poland; email: bkowal@agh.edu.pl

2) Ph.D., DSc, Eng.; Silesian University of Technology, Gliwice, Poland; email: malgorzata.wyganowska@polsl.pl

\author{
http://doi.org/10.29227/IM-2020-01-80
}

Submission date: $12-12-2019$ | Review date: 01-02-2020

\section{Abstract}

The paper presents an analysis of selected aspects of motivation and engagement of hard coal mine employees working in longwall faces. The analysis of survey results covers selected questions from a broader survey conducted in the analyzed mining companies. The miners had a negative opinion on the incentive programme in their workplaces, stating that it is ineffective. The survey also included factors affecting the engagement of the entire research sample in their work, showing their significance level for the respondents.

Keywords: motivation, mining companies, energy sector, miners, engagement in work

\section{Introduction}

The issue of the remuneration system in the mining industry and its components has been studied relatively rarely so far and is still not very frequently addressed in the literature. A small number of publications concerning the Polish mining industry stems from the fact that this issue is rather complex, mainly due to numerous documents governing wage matters in the mining industry or different arrangements of remuneration components.

The main publications discussing the issue of the incentive programme are those that address the issue of cafeteria plans in the mining sector as one of the elements of human resource strategy [1] and the classification of employees for the purposes of staff management in the mining industry [1, $2,3,4,5]$. The literature also includes publications on motivational aspects of remuneration systems in the mining industry. They concern roadway works [6], a participation-based incentive programme for the longwall crew [7], work value hierarchy and personal factors [8], or project team incentive programmes [9]. The issue of motivation in mining companies was mentioned in several publications, including $[10,11,12,13]$. The aforementioned research revealed that employees are motivated to comply with OHS rules mainly by non-financial factors such as the sense of responsibility for their family and relatives, for themselves and their colleagues, good work organisation, or correct behaviour of superiors. The respondents did not value financial stimuli as much. Motivation for working safely was also the subject of research among miners, which showed that rewarding for safe work is necessary, while the use of wage measures may have a positive effect on the motivation for working safely, which is in conflict with the aforementioned research results [14]. It is worth mentioning that trainings in this field are a necessary complement of motivating miners to work safely $[15,16]$. And organizational culture in the mining industry has the best impact on shaping miner's awareness of occupational health and safety $[17,18]$.
The restructuring of the mining sector, which has been ongoing for many years, aims to adapt both the business structure and economic efficiency to the current market requirements $[19,20,21,22,23]$. In the current situation of the mining industry, the issues raised in the article are undoubtedly very important, which is highlighted by one of the main documents regulating the functioning of mining sector in Poland, " Programme for the hard coal mining sector in Poland ". It points the low share of incentives in remuneration systems as one of the weaknesses of the hard coal mining sector [24]. The current situation of the mining industry should be used by managers to make modifications in remuneration systems $[25,16]$.

\section{Methodology and Data}

Research on the system of motivation and engagement of employees in their work was carried out in two mining companies operating in Upper Silesia. The research sample included hard coal mine employees working in faces.

The research was quantitative, performed with the use of the Delphi method, and used the knowledge, experience, and opinions of experts. At the beginning, the statistical sample consisted of a much higher number of surveys but 169 surveys that were correctly filled in and did not raise any doubts were eventually analysed. The number of the respondents in PG-1 (Mining Company 1) and PG-2 (Mining Company 2) was 103 and 66 respectively. The analysis of the survey results presented later in the paper concerns selected questions from a broader survey of the analysed mining companies.

The aim of the surveys was to gain knowledge about work motivation and engagement of miners working in longwall faces. The five-point Likert scale was used for the question where the miners assessed the current incentive programme. For the question concerning employee engagement, the responses were scaled, i.e. the sum of the results for each factor was converted into an appropriate significance percentage in the group. Scaling was done using the formula below (1): 


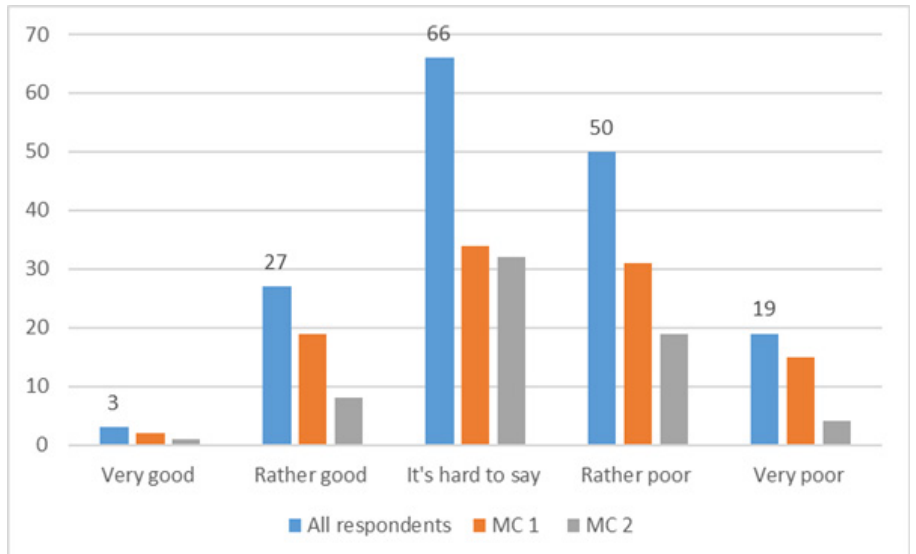

Fig. 1. Assessment of the incentive programme by miners in the analysed mining companies. Source: authors' own elaboration based on research results Rys. 1. Ocena systemu motywacyjnego przez górników w analizowanych przedsiębiorstwach górniczych. Źródło: opracowanie własne na podstawie wyników badań

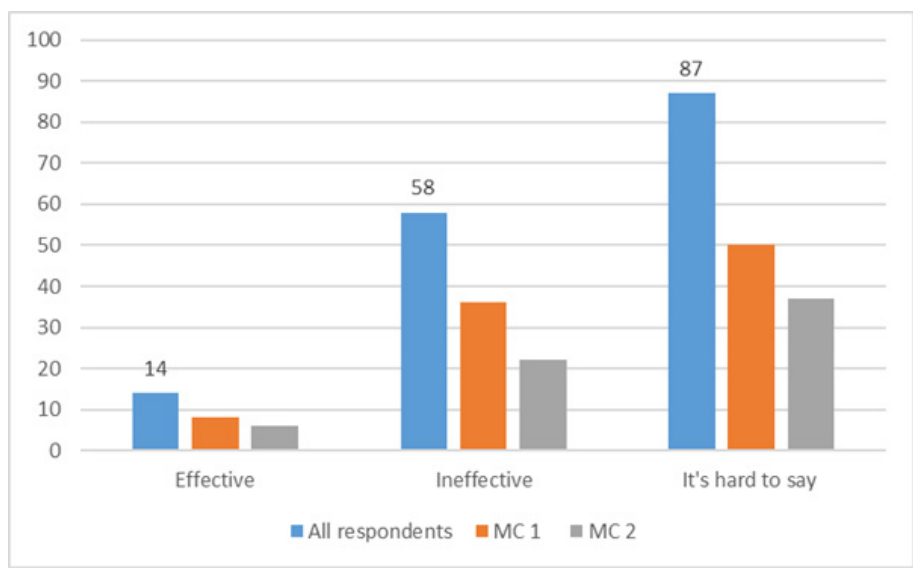

Fig. 2. Assessment of the incentive instruments currently used in the analysed mining companies. Source: authors' own elaboration based on research results

Rys. 2. Ocena obecnie stosowanych narzędzi motywowania w analizowanych przedsiębiorstwach górniczych. Źródło: opracowanie własne na podstawie wyników przeprowadzonych badań

$\frac{(\text { SUM }- \text { number of respondents })}{(4 \times \text { number of respondents })} \times 100 \%$

\section{Results}

It is without doubt that the incentive programme affects the feeling of being appreciated for one's work and the need of rewarding. The analysed occupational group was asked to assess the incentive programme in their workplace. Only four respondents did not answer this question, while the results obtained were a bitter disappointment. Figure 1 shows that as many as $80 \%$ of the respondents rated the incentive programme as poor, while less than $20 \%$ as "rather good". In both mining companies, the majority of the responses were "it's hard to say" (34 and 32 in PG-1 and PG-2 respectively). Should the response "it's hard to say" be omitted, 46 respondents (almost 45\%) in PG-1 think that the incentive programme is poor, while approx. $20 \%$ (21 respondents) think it is rather good. In PG-2, approx. $13 \%$ of the miners (9 respondents) rate the programme as good, while over $30 \%$ rate it as poor (23 respondents).

Based on the response to the question about the assessment of the incentive programme in respondents' workplaces, it can be concluded that it functions poorly in hard coal mines or it does not have the so-called driving force. The next ques- tion, concerning the assessment of the incentive instruments used, serves as a confirmation of the respondents' opinion. The vast majority of the respondents think that they are not effective (Fig. 2). The responses were very similar in both mining companies. The majority of the respondents said that it is difficult for them to assess the instruments currently used. This group included 87 respondents, i.e. more than $50 \%$ of the respondents. Fifty-eight respondents (approx. 35\%) rated them as ineffective, with only 14 respondents $(8 \%)$ in both mines rating them as effective.

This should not be the case because, after all, the incentive programme should make the employee satisfied with the work that he/she performs and the conditions where he/she performs it. The most important function of the incentive programme is to make the employee identify with the company. He/she feels more connected with the company, hence the engagement in his/her work increases.

Given that the surveyed occupational group rated the incentive programme in the industry as poor and rated the incentive instruments used as ineffective, they were also asked about the frequency of granting bonuses. The bonus is one of the main incentive instruments. It is included in optional components of remuneration, which means that a company can but does not have to use it. For both compa- 


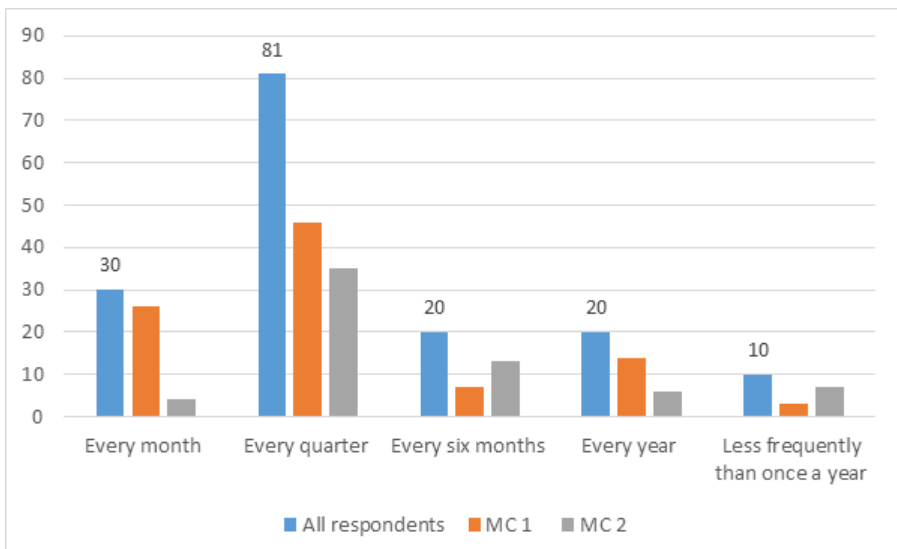

Fig. 3. Frequency of granting bonuses in the analysed mining companies. Source: authors' own elaboration based on research results Rys. 3. Częstotliwość przyznawania premii w analizowanych przedsiębiorstwach górniczych. Źródło: opracowanie własne na podstawie wyników przeprowadzonych badań

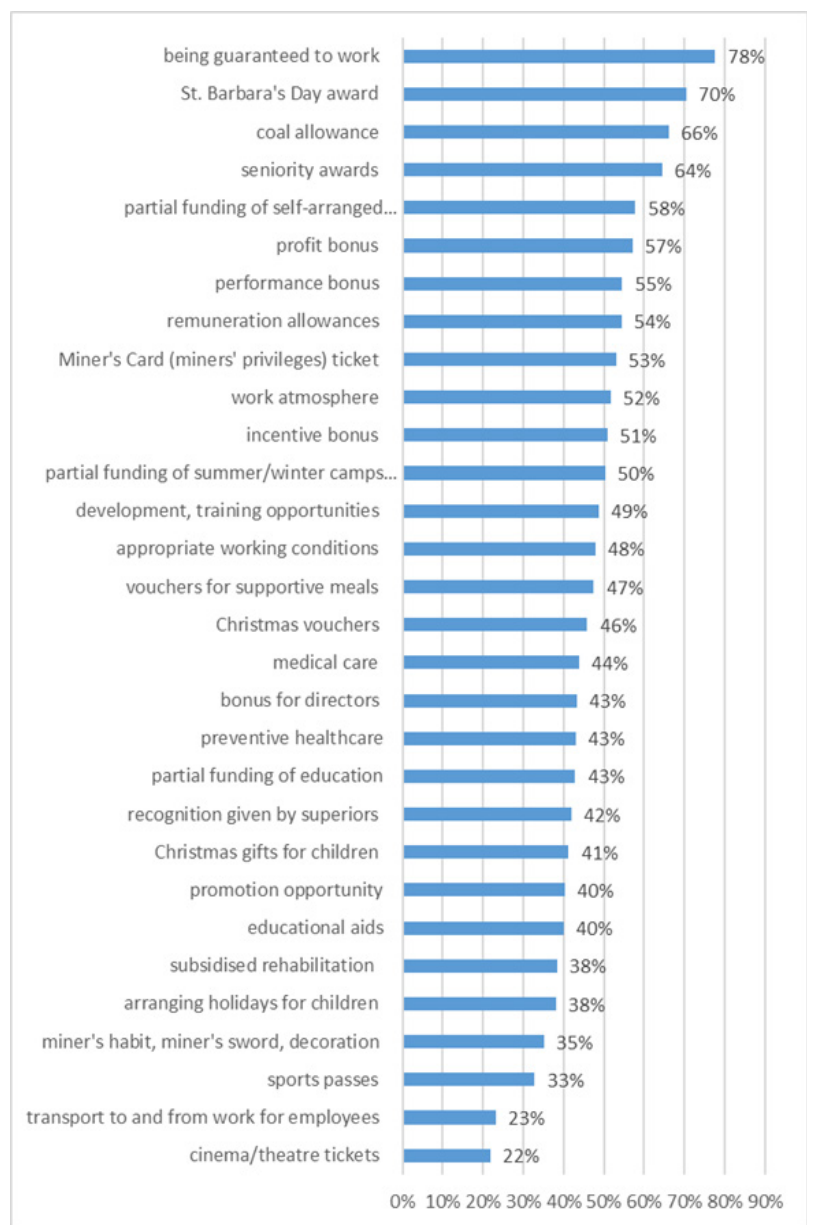

Fig. 4. Factors affective miners' engagement in their work in the analysed mining companies. Source: authors' own elaboration based on research results Rys. 4. Czynniki wpływające na zaangażowanie górników w pracę w analizowanych przedsiębiorstwach górniczych. Źródło: opracowanie własne na podstawie wyników przeprowadzonych badań

nies, it can be observed that quarterly bonuses are the most common (Fig. 3). They were indicated by as many as half of the respondents (46 PG-1 respondents, i.e. $45 \%$, and 35 PG-2 respondents, i.e. 53\%). More responses concerned monthly bonuses (26 respondents, $25 \%$ ) in the first company than in the other (only 4 respondents, $6 \%$ ) as well as yearly bonuses (14 respondents in PG-1 and 6 respondents in PG-2). Eight respondents did not say how often bonuses are given to them.
Generally, bonuses supplement the base remuneration, reinforcing the motivational nature of remuneration. On one hand, paying bonuses on a quarterly or monthly basis does not generate too high costs for the employer in a single settlement period with the employee. On the other hand, the amount of an annual bonus would certainly be higher, which would result in the accumulation of costs for the employer but also in an increased employee satisfaction due to a one-off payment of the accumulated bonus. 
In addition to the considerations of motivating and engaging miners in their work, they were asked to specify how much impact the mentioned factors have on them on a scale from 1 to 5 , where 1 meant low impact, while 5 large impact (a factor strongly affects the respondent). Scaling was used for this question. The respondents' answers were scaled, i.e. the sum of the results for each factor was converted into an appropriate significance percentage in the group (1).

It is not hard to notice that when all respondents rate a given question the lowest (i.e. 1), the significance percentage obtained from the formula equals 0 , but when all respondents rate it the highest (i.e. 5), the percentage is $100 \%$. This linear scaling makes it easier to interpret the significance of individual answers and makes it possible to compare groups of different sizes as well as the entire sample, including the division into individual companies.

The analysis of the entire research sample results shows that being guaranteed to work (78\%), thus being guaranteed to receive remuneration, is the most important factor for the respondents. Factors of a slightly less significance for the respondents also included: St. Barbara's Day award (70\%), coal allowance (66\%), and seniority awards (64\%). Factors affecting the respondents' engagement in their work and having a significance in the range of $50-60 \%$ included:

- partial funding of summer/winter camps for children;

- incentive bonus;

- $\quad$ work atmosphere;

- Miner's Card (miners' privileges) ticket

- remuneration allowances;

- performance bonus;

- profit bonus;

- partial funding of self-arranged countryside holiday.

Medium-impact factors with a significance in the range of $40-50 \%$ included: promotion opportunity (40\%), Christ- mas gifts for children (41\%), recognition given by superiors (42\%), partial funding of education, preventive healthcare, and bonus for directors (43\%), medical care (44\%), Christmas vouchers (46\%), vouchers for supportive meals (47\%), appropriate working conditions (48\%), and development, training opportunities (49\%).

Figure 4 shows the significance level of factors affecting the engagement of the entire research sample.

The following factors have a low impact on engagement: cinema/theatre tickets, transport to and from work for employees, sports passes, miner's habit, miner's sword, decoration, arranging holidays for children, medical care.

\section{Discussion and Conclusions}

One of the weaknesses of the hard coal mining sector presented in the strategic analysis in the "Programme for the hard coal mining sector in Poland" included low participation of incentive instruments in remuneration systems and excessive fragmentation of remuneration components. The mining industry has been unable to tackle this issue for a long time, while the ongoing restructuring processes put changes in the incentive programme on the back burner. The surveys reveal that the incentive programme is ineffective in the analysed mining companies. The factors engaging miners in their work obviously include financial factors. A quarterly bonus is one of them.

The presented research conclusions can be used to modify existing remuneration systems in the mining and energy sectors, with particular emphasis on increasing the share of incentives in remuneration systems.

\section{Acknowledgement}

This paper was supported by the AGH University of Science and Technology [No. 16.16.100.215]. 


\section{Literatura - References}

1. Bator, A.; Ślósarz, M. Cafeteria remuneration systems in the mining sector, Przegląd Górniczy 2009, nr 9, s. 52-54. [in Polish]

2. Ślósarz, M. The concept of employee classification for the needs of personnel management in a mining company, Przegląd Górniczy 2010, nr 9, 97-99. [in Polish]

3. Ślósarz, M. Implementation of employee classification for the needs of the cafeteria remuneration system in the enterprise, [w:] R. Knosala (red.), Komputerowo zintegrowane zarządzanie, T. 2, Oficyna Wydawnicza Polskiego Towarzystwa Zarządzania Produkcją, Opole 2011, 423-428. [in Polish]

4. Ślósarz, M. Employee classification method in a mining company, Przegląd Górniczy 2011, nr 9, 157-159. [in Polish]

5. Ślósarz, M. Management of modern employee remuneration systems, Studia i Materiały „Miscellanea Oeconomicae” 2012, Wydział Zarządzania i Administracji Uniwersytetu Humanistyczno-Przyrodniczego Jana Kochanowskiego, R.16 nr 2, 197-206. [in Polish]

6. Gruca, P.; Lacheta, A. Elements of the incentive system for corridor works of hard coal mines, Przegląd Górniczy 1984, nr 7-8, s. 266-273. [in Polish]

7. Lisowski, A. A participatory incentive system for the wall crew (system PSM-Ś), Wiadomości Górnicze 1992, nr 12, 275-278. [in Polish]

8. Kutkowski, J.; Zaniewski, K. The role of work value and personal factors in effective production management, Przegląd Górniczy 2010, nr 9, 100-103. [in Polish]

9. Tchórzewski, S. Analysis and evaluation of project team motivation systems, Wiadomości Górnicze 2011, nr 2, 77-81. [in Polish]

10. Tobór-Osadnik, K.; Wyganowska, M. Attitudes towards work safety and employment security in Polish hard coal mining enterprises, Wiadomości Górnicze 2012, nr 10, 578-585. [in Polish]

11. Tobór-Osadnik, K.; Wyganowska, M. Material incentives in incentive systems in Polish hard coal mining enterprises, Przegląd Górniczy 2013, nr 4, 127-133. [in Polish]

12. Tobór-Osadnik, K.; Wyganowska, M. Motivating hard coal mine employees to comply with health and safety regulations, Wiadomości Górnicze 2014, nr 11, 591-600. [in Polish]

13. Kowal, B. An analysis of the expectations of an occupational group of miners based on the example of Polish mining. W: SGEM - 5 international multidisciplinary scientific conference on Social sciences and arts. Bulgaria: conference proceedings. 2018 vol. 5, Business and management. Iss. 1.5, Modern science. ISSN 2367-5659. 55-62, DOI: $10.5593 /$ sgemsocial2018/1.5.

14. Wandzich, D.; Walkiewicz, B.; Płaza, G. The role of motivating factors in the miners' professional group, Zeszyty Naukowe Politechniki Śląskiej, Seria: Organizacja i Zarządzanie 2014, z.71, nr kol. 1917, s. 305-314. [in Polish]

15. Bąk, P.; Sukiennik, M.; Kapusta, M. The issues related to occupational health and safety culture in the mining industry. W: Contemporary management in extractive industries - multidimensional and practical approach: monography, Jonek-Kowalska I. (ed.). Wydawnictwo Politechniki Śląskiej, Gliwice 2019. ISBN: 978-83-7880-646-2, 247-259.

16. Kowal, B. Analysis of the comfort life and work in the assessment of the occupational group of employees in the energy sector on the basis of a mining company, E3S Web of Conferences: Energy and fuels 2018, ISSN 2267-1242, vol. 108 art. no. 02016, 1-11. https://www.e3s-conferences.org/articles/e3sconf/pdf/2019/34/e3sconf_ef18_02016. pdf.

17. Kapusta, M.; Bąk, P.; Sukiennik, M. A strategic analysis of selected factors that create the culture of occupational health and safety in mining companies in Poland, part 1. Journal of the Polish Mineral Engineering Society 2019. ISSN 1640-4920, R. $21 \mathrm{nr} 2,287-292$.

18. Kowal, B.; Wiśniowski, R.; Ogrodnik, R.; Młynarczykowska, A. Selected elements of a safe work environment in hard coal mines in the Polish mining sector. Journal of the Polish Mineral Engineering Society 2019, ISSN 1640 4920, R. 21 nr 2, 215-223. http://www.potopk.com.pl/Full_text/2019_full/IM\%202-2019-a35.pdf.

19. Manowska, A.; Nowrot, A. The importance of heat emission caused by global energy production in terms of climate impact. Energies 2019, vol. 12 iss. 16, 1-12. https://doi.org/10.3390/en12163069.

20. Ranosz, R. Analysis of the structure and cost of capital in mining enterprises. Mineral Resources Management 2017, ISSN 0860-0953. vol. 33 iss. 1, 77-91.

21. Karbownik, A. Coal mining in Poland. Assessment of the current state (ed. Bochniarz H., Krajewski S., Sectoral restructuring programs and privatization of state assets. Selection of expertise 1997, 80-100. [in Polish] 
22. Manowska, A.; Rybak, A. Analysis of employment in the mining sector taking into account the forecasted demand for hard coal, 4th International Multidisciplinary Scientific Conference on Social Sciences and Arts, Bulgaria, Conference proceedings. Book 1, Modern science. 2017, vol. 5, Business and management, 75-82, DOI: 10.5593/ sgemsocial2017/15/S05.010.

23. Manowska, A.; Rybak, A. The future of hard coal compared to other energy carriers, 4th Polish Mining Congress, IOP Conf. Series: Earth and Environ. Sci. 2018, vol. 174, 012007.

24. Program dla sektora górnictwa węgla kamiennego w Polsce, Ministerstwo Energii, Warszawa 2018. [in Polish]

25. Kowal, B. New trends in remuneration schemes for underground workers in hard-coal mines, Wydawnictwa AGH, ISSN 0867-6631, Kraków 2019. [in Polish]

\section{Elementy motywacji i zaangażowania pracowników w wykonywana pracę na przykładzie} przedsiębiorstw górniczych

Artykuł prezentuje analizę wybranych aspektów motywacji oraz zaangażowania pracowników zatrudnionych w kopalniach węla kamiennego, pracujacych na stanowiskach robotniczych w przodkach ścianowych. Przedstawione w artykule analizy wyników badań ankietowych obejmują wybrane pytania $z$ szerszego badania przeprowadzonego w analizowanych przedsiębiorstwach górniczych. Górnicy negatywnie ocenili istniejący w ich zakładach system motywacyjny stwierdzając, że jest on nieskuteczny. Badanie objęło również czynniki wplywające na zaangażowanie całej próby badawczej w pracę, pokazując ich poziom istotności dla ankietowanych.

Słowa kluczowe: motywacja, przedsiębiorstwa górnicze, sektor energetyczny, górnicy, zaangażowanie w prace 